\title{
Debats socio-científics al voltant dels processos d’extracció i emmagatzematge d’hidrocarburs
}

\author{
Raquel Rios Font (Raquel.Rios@uab.cat) Centre de Recerca per a l'Educació Científica i Matemàtica \\ (CRECIM). Universitat Autònoma de Barcelona. \\ Enrique Luque López (potrikk@hotmail.com), Llicenciat en Química per la Universitat de València i mem- \\ bre de Ecologistes en Acció i de la Plataforma Antifracking Comarques de Castelló.
}

\begin{abstract}
Aquesta tardor els diaris, tertúlies radiofòniques i programes informatius de televisió han anat plens de notícies relacionades amb els terratrèmols que van tenir lloc a la costa de Castelló i de les Terres de l'Ebre. Al mateix temps, eren notícia també diversos moviments i protestes promogudes per plataformes arreu del territori espanyol en oposició a la tècnica de la fractura hidràulica o "fracking", la qual de vegades, per confusió, s'associa a la causa de l'activitat sísmica detectada recentment a Castelló. En aquest article descriurem breument aquesta tècnica extractiva així com el procés que va desencadenar els terratrèmols, $i$ exposarem també alguns arguments $i$ opinions que s'han manifestat en contra d'aquests tipus d'intervencions.
\end{abstract}

Paraules clau: gas natural, extracció, petroli, Castor, fractura hidràulica, fracking, terratrèmols

Durant els darrers mesos han aparegut a diversos mitjans de comunicació una gran quantitat de notícies relacionades amb els terratrèmols que van tenir lloc a la costa de Castelló i de les Terres de l'Ebre durant la passada tardor. Aquesta activitat sísmica va ser provocada, segons han apuntat alguns experts, pels treballs realitzats a la planta de gas que l'empresa Castor té davant la costa de Vinaròs i Alcanar. Al mateix temps, darrerament han estat sent notícia també els moviments i protestes promogudes per diverses plataformes arreu del territori espanyol que s'oposen a l'aplicació de la fractura hidràulica o "fracking". Malgrat que els terratrèmols abans esmentats no van ser provocats per l'aplicació de la tècnica del fracking sinó per les operacions d'injecció de gas natural en el projecte d'emmagatzematge subterrani a l'antic jaciment petrolífer d'Amposta, d'aquest episodi se'n poden extreure algunes lliçons sobre la sismicitat potencial que poden produir les operacions de fractura hidràulica (Simón Gómez, 2013).

Davant d'aquest context, és necessari tenir clar quines són les principals característiques d'aquestes dues estratègies que tenen per objectiu assegurar la provisió d'hidrocarburs per tal de poder-les distingir i tenir una opinió fonamentada al respecte. A més, la rellevància social d'aquest tema el fa especialment interessant per al plantejament de debats en el context de les classes de ciències. Per aquests motius, hem demanat a Quique Luque (llicenciat en Ciències Químiques per la
Universitat de València, i membre dels col-lectius Ecologistes en Acció Vinaròs des de 1982 i de la Plataforma Antifracking Comarques de Castelló des de 2002), que ens aclareixi alguns dubtes al respecte.

\section{En què consisteix l'emmagatzematge de gas portat a terme a la planta Castor?}

El projecte Castor va començar la seva marxa per l'any 1996 amb l'inici d'estudis previs per avaluar la possibilitat de reconvertir un antic jaciment de petroli convencional sobre roques calcàries poroses (krastificades) en la mar (explotat en el període 1973-1989 per les empreses Shell/Campsa), en un magatzem de gas en estat líquid. Posteriorment, l'any 2008, el Govern d'Espanya dóna el vistiplau a la "Sol-licitud de Concessió d'Emmagatzematge Subterrani de Gas Natural Castor de l'empresa Escal UGS S.L." i es construeixen diverses infraestructures importants per poder bombar, extreure i emmagatzemar el gas. Per tal de poder fer això, es necessita: (i) la matèria primera principal (el gas ciutat o metà) que serà alimentat a través de la xarxa nacional de gasoductes (en el nostre cas, el branc Tivissa-Paterna); (ii) una planta terrestre de bombament i cremat de gas (situada a Vinaròs); (iii) una antiga plataforma petrolífera readaptada (a $21 \mathrm{~km}$ de la costa de Vinaròs-Castelló) i ancorada al fons marí, per crear pous (fins a vuit) d'injecció/extracció en diferents zones del jaciment i 
per poder treballar en unes condicions controlades de pressió, cabal, etc.; i (iv) un gasoducte submarí connectat a la planta terrestre de bombament. La resta són obres, condicions de treball, seguretat i pura enginyeria. El resultat és intentar emmagatzemar, a uns $2 \mathrm{~km}$ per sota del nivell del mar, 1.900 milions de metres cúbics- $\mathrm{Mm}^{3}$ (1,9 bilions de litres) de gas metà per actuar com a reserva estratègica estatal (Escal UGS, 2007) i poder ser extret, en cas de necessitat, per ser novament recirculat a la xarxa de gasoductes existents al territori estatal (s'estima que podria nodrir les necessitats de tot l'estat durant 45 dies). Fins aquí tot sembla fantàstic, però això no està exempt de risc:

- La zona escollida és sísmicament activa i amb falles actives [1]. El pou central se situa sobre la falla Amposta (de $51 \mathrm{~km}$ ) que segella la fossa d'emmagatzematge en la seva part més occidental. Qualsevol desequilibri de tensions crearia una sismicitat anticipada (anticipem tremolors que potser no es produirien de forma natural fins a dins de milers d'anys).

- La zona escollida per al magatzem de gas està molt fracturada i forçada a causa de les antigues extraccions de petroli (cal tenir en compte que es van extreure més de 56 milions de barrils de cru en 16 anys d'explotació), amb la qual cosa és inestable i podria enfonsar-se (De las Doblas et al, 2013). Els fenòmens d'expansió/dilatació (quan s'injecta gas) i contracció (quan s'extrau gas), portarien a una sismicitat induïda (fomentaríem nous tremolors i trencaments de materials).

- L'estudi dels materials que recobreixen el jaciment indica que suportarien una pressió de 291 atmosferes, amb la qual cosa caldria controlar molt bé les condicions de treball, no sols amb les pressions d'injecció i cabals injectats, sinó també amb la pressió total de l'emmagatzemat. Fins al moment, amb la injecció de menys de la meitat del previst, ja s'han provocat més de 600 tremolors, alguns de fins a 4,2 graus en l'escala Richter, amb la qual cosa la zona és realment inestable i perillosa.

\section{Hi ha antecedents sobre l'ús d’aquest tipus de tècnica a l'Estat Espanyol?}

Existeixen altres tres magatzems de gas [2] en diferents punts de l'estat: "Serrablo" a SabiñánigoOsca, 1984, amb capacitat per a $1.100 \mathrm{Mm}^{3}$; "Gavina" a Bermeo-Biscaia, 1986, amb capacitat per a $2.681 \mathrm{Mm}^{3}$, i "Yela" a Brihuega-Guadalajara, 2012 amb capacitat per a $2.000 \mathrm{Mm}^{3}$. D'aquests magatzems, només el de Bermeo se situa a nivell marí (mar Cantàbric, a 8 km de la costa) encara que les característiques geològiques i d'emmagatzematge són diferents al de Castor, ja que es tracta d'un antic jaciment de gas esgotat i una zona sense problemes de falles actives. En cap de les zones esmentades, que se sàpiga, hi ha hagut problemes sismològics i geològics importants.

\section{En què consisteix és el "fracking" o fractura hidràulica?}

Es tracta d'una tècnica relativament nova que compta amb més de 30 anys d'experiència a Estats Units i neix com un intent de independència energètica pel constant increment del preu del petroli. Consisteix a extreure hidrocarburs no convencionals (o sigui petroli i gas originats per la descomposició de la matèria orgànica que es troben a grans profunditats, en petites quantitats i que són de difícil extracció) mitjançant una perforació en vertical (normalment més de $3 \mathrm{~km}$ ) i diversos quilòmetres en horitzontal. Aquestes perforacions són utilitzades per fracturar els materials adequats amb explosius i arribar a majors superfícies de gas potencial. Així mateix s'injecten a alta pressió (de 400 a 700 atmosferes) líquids formats per aigua, sorra i additius químics per fomentar així la migració dels hidrocarburs (normalment gas metà) cap a les conduccions d'extracció, i evitar el tancament natural de les roques fracturades, que a aquestes profunditats i amb les pressions existents, ho farien ràpidament (Cotarelo et al, 2012).

Per tal que aquesta tècnica arribi a ser exitosa, prèviament, en la seva fase d'estudi, ha de fer-se un meticulós estudi geològic per esbrinar les zones amb major probabilitat d'existència d'hidrocarburs i les seves possibles afeccions a aqüífers, falles actives, etc. Recordem que el gas no convencional es troba, normalment, en dipòsits profunds (a més de $5 \mathrm{~km}$ ); en sorres compactes; en esquists o pissarres bituminoses, i en betes de carbó. En la seva fase de recerca i explotació, cal crear camins d'accés i adequar la zona de treball (desforestacions de diverses hectàrees en zones arbrades, anivellacions de terreny, etc.). A més, caldria construir basses per emmagatzemar líquids, tant d'injecció com de residus, així com muntar pous de perforació i iniciar els processos extractius en les condicions tècniques adequades. Normalment, els pous (amb vàries fractures hidràuliques) solen caure en els seus rendiments cada 3 anys, amb la qual cosa cal obrir nous pous al voltant de l'anterior per aconseguir bons rendiments en l'extracció de gas, de manera que aquesta activitat industrial pot crear en l'entorn l'efecte formiguer.

En cada pou d'extracció i cada vegada que es realitza una operació de fractura hidràulica o frac- 
king, s'utilitzen una mitjana de 19 milions de litres d'aigua dolça que conté un $2 \%$ d'additius químics. D'aquest líquid injectat, se'n sol recuperar (fluït de tornada) entre el $15-80 \%$, que seria emmagatzemat en superfície en les basses impermeabilitzades a l'aire lliure, quedant la resta perduda a l'interior de l'escorça terrestre. Els additius químics són còctels secrets amb àcids, reductors de viscositat, bactericides, inhibidors d'oxidació, etc., que arriben a contenir fins a 600 substàncies químiques amb diverses utilitats tecnològiques i diferents graus de perillositat.

\section{Existeixen antecedents sobre l'ús d’aquest tipus de tècnica a l'Estat Espanyol?}

No, no existeixen grans antecedents històrics sobre l'ús del fracking a Espanya ja que és una tècnica recent. El 2006 va ser aprovat el projecte, anomenat "Gran Enara", que afectava a 325.000 hectàrees a Burgos, Àlaba, Cantàbria, Biscaia i Navarra (Simón Gómez, 2013). Encara que només són projectes de recerca, les perforacions amb la utilització del fracking són imminents.

L'auge per la recerca i explotació d'hidrocarburs a la Península Ibèrica va arribar per l'any 1950, localitzant-se diverses zones amb potencial important a Burgos, mar Mediterrani, golf de València, vall del Guadalquivir i golf de Cadis i fent prospeccions a molts més llocs del territori. El primer pou de petroli, amb extracció d'hidrocarburs convencionals, va tenir lloc el 1964 en l'Erm de la Lora (Burgos) i, allà, amb trenta pous actius, en tres anys es van arribar a extreure 19 milions de barrils de cru, esgotant-se ràpidament la seva extracció a causa de la fracturació del terreny i el seu difícil accés, que van convertir la resta de les reserves en inaccessibles (convertint-se, per tant, en hidrocarburs no convencionals). En no haver-hi tecnologia per explotar-los, es van abandonar fins que la ciència creés tècniques per fer-los explotables i rendibles (com ara la fractura hidràulica o fracking).

\section{En quines zones del territori espanyol s'ha intentat aplicar aquesta tècni- ca?}

Actualment gairebé totes les Comunitats Autònomes compten amb sol-licituds de projectes de recerca per a l'extracció d'hidrocarburs amb la utilització de la tècnica del fracking [3]. La major part estan en fase d'aprovació (Andalusia, Castelló, Catalunya, Terol, Saragossa, etc.), però n'hi ha alguns d'aprovats (País Basc, Burgos i Cantàbria) on, si no es remeia (legislació, oposició ciutadania, oposició política, etc.), pròximament començarà l'activitat in- dustrial malgrat les grans llacunes ambientals, sanitàries i sísmiques que s'han manifestat en altres països (EUA, Gran Bretanya i Polònia).

\section{Quins inconvenients per al territori pot comportar l'aplicació d’aquesta tècnica?}

Són molts els impactes que s'atribueixen a la fractura hidràulica a tenor de l'esdevingut en els milers de pous perforats als EUA des dels anys 70 . Els més importants són riscos geològics i sismicitat, impactes al medi ambient, contaminació d'aqüífers, impactes sobre la salut dels ciutadans, etc. Vegem alguns exemples representatius:

- D'una banda cal parlar d'una elevada ocupació del territori a causa de les plataformes de perforació, aparcaments i àrees de maniobres per a camions, equipament, processament del gas i instal-lacions de transport, així com carreteres d'accés, augment del tràfic, accidents i abocaments, desforestacions, impactes paisatgístics, sorolls, etc.

- Per altra banda, l'ús de l'aigua per a la fractura hidràulica és important, no solament per la quantitat d'aigua dolça necessària (s'estimen consums de 9.000 a $29.0000 \mathrm{~m}^{3}$ per pou d'explotació i operació de fractura) sinó també perquè pot haver-hi contaminació de la mateixa amb substàncies químiques i saturació de gas. Per exemple, al nord-est de la província de Castelló s'han fet estudis tècnics específics [4], encarregats per la pròpia administració, i han conclòs, com a recomanació, no autoritzar els projectes per l'alta probabilitat de contaminació de l'aqüífer Javalambre/Maestrat).

- Respecte els residus, principalment d'aigües (entre 1 i 23 milions de litres per explotació) i llots contaminats, existeixen greus problemes per al seu tractament, i en molts casos podrien passar fàcilment a les cadenes tròfiques per filtracions, evaporacions, vessaments, etc.

- Sobre els additius químics utilitzats, és clar que s'utilitzen còctels de diferent perillositat per al medi ambient i la salut. La injecció subterrània de productes químics tòxics barrejats amb aigua i sorres, i on poden no recuperar-se, és una autèntica temeritat. De les dades cedides per la indústria americana a les administracions d'EUA sobre la composició d'alguns d'aquests còctels químics, se'n desprèn l'existència de substàncies tòxiques, cancerígenes, mutagèniques, etc.

- Sobre la geologia dels terrenys afectats, caldria fer estudis geològics seriosos per estudiar els seus materials, fracturacions, karstificació, 
elevacions, enfonsaments, etc., i així determinar la fragilitat del terreny quant a possibles tremolors sísmics, fragilitat dels aqüífers, etc.

- Sobre possibles riscos sismològics, cal avaluar seriosament la informació disponible en els organismes especialitzats i la informació geològica de cada zona (Simón Gómez, 2013). Serveixin d'exemple els terratrèmols històrics detectats després de la utilització del fracking en diferents països:

- Arkansas (EUA): el 90\% dels sismes detectats des de 2009 estan a $6 \mathrm{~km}$ de pous on s'ha injectat aigua tòxica de deixalla.

- Ohio (EUA), desembre 2011: es van detectar una desena de sismes de fins a 4 graus a l'escala de Richter a les zones properes als pous de fracking.

- Al març del 2011, dues companyies americanes de fracking van suspendre la seva activitat per estudiar la relació entre les activitats d'injecció de líquids i els 800 sismes ocorreguts en els últims 6 mesos. Després del tancament dels pous el nombre de sismes va disminuir.

- Gran Bretanya, juliol 2011: dos sismes d'1.5 i 2.3 a l'escala de Richter van produir-se a 500 m del lloc d'extracció.

\section{CONCLUSIONS}

El fet que la nostra societat sigui altament depenent dels recursos fòssils com el petroli i el gas natural no és cap novetat [5]. L'extracció d'aquests combustibles que s'han anat generant al llarg de centenars de milers d'any ha permès que actualment tinguem un determinat nivell de vida, però tal $\mathrm{i}$ com apunta el Professor Mariano Marzo (2013), catedràtic en Estratigrafia i professor de Recursos Energètics i Geologia a la Universitat de Barcelona, ara ens trobem amb un "trilema" energètic: la nostra sostenibilitat energètica dependrà de la capacitat de trobar l'equilibri entre els tres eixos que conformen la política energètica del país, com són el medi ambient, l'economia i la seguretat de subministrament.

El sector energètic està en auge en totes les comarques i territoris de l'estat. Macro magatzems subterranis de gas; explotació d'hidrocarburs no convencionals utilitzant la fractura hidràulica; línies de molt alta tensió; cerca de nous jaciments d'hidrocarburs convencionals en el mar i els oceans, etc. És la nova bombolla econòmica en la qual han invertit nombroses empreses abans dedicades a la construcció de grans infraestructures i l'urbanisme. Es fomenta el consum i no hauríem d'oblidar els potencials impactes que aquestes activitats generen, doncs al cap i a la fi, es tracta de recursos fi- nits i fòssils; amb grans impactes i generadores de massa inseguretats. El nostre futur energètic hauria d'encaminar-se cap a la reducció en el consum, la utilització de fonts renovables d'energia, la recerca i l'autosuficiència energètica.És necessari un autèntic canvi de mentalitat i un gir progressiu però ferm, en les polítiques energètiques. Aprofitar els últims reductes d'hidrocarburs allarga la nostra agonia energètica i aprofundeix encara més en els greus problemes de canvi climàtic, agressions ambientals, pèrdua d'ecosistemes i biodiversitat, i en resumides comptes, alteració gradual del planeta Terra. No ens ho podem permetre.

\section{BIBLIOGRAFIA I REFERÈNCIES}

SIMÓN GÓMEZ, J.L. (2013), Valoración del riesgo de sismicidad inducida por eventuales operaciones de fracking en el entorno de fallas activas en el norte de la provincia de Castellón. Universidad de Zaragoza.

ESCAL UGS (2007). Memoria Técnico-Económica del Proyecto de Concesión de Explotación de Almacenamiento Subterráneo de Gas Natural Castor.

DE LAS DOBLAS, M. el al. (2013). Riesgos potenciales derivados de la inyección de gas en la Plataforma Castor. Ecologistas en Acción. Madrid.

http://www.ecologistasenaccion.org/article26325 .html

COTARELO, P. et al. (2012). Agrietando el futuro. La amenaza de la fractura hidráulica en la era del cambio climático. Ed. Libros en Acción (Ecologistas en Acción). Madrid.

MARZO, MARIANO (2013), Recursos energètics. D'on ve l'energia? Sessió teòrica durant les I Jornades sobre energia i tecnologia per a professors al Museu del Gas (Sabadell).

[1] Quaternary Active Faults Database of Iberia v.2, Instituto Geológico y Minero de España. http://www.igme.es/infoigme/aplicaciones/qafi/

[2] Enagas: http://goo.gl/vNcbMu

[3] Ministerio de Industria, Turismo y Comercio: http://www6.mityc.es/aplicaciones/energia/hidrocarb uros/petroleo/exploracion2012/mapas/inicio.html

[4] Informe Hidrocarburos. Diputació de Castelló: http://www.dipcas.es/es/descargas/

[5] A Espanya, el $50 \%$ del consum d'energia prové de derivats del petroli.

http://diariolinea.blogspot.com.es/2011/02/maria no-marzo-catedratico-de-recursos.html 